PNL-3191

UC-94b

\title{
The Economics of Compressed Air Energy Storage Employing Thermal Energy Storage
}

S. C. Schulte

R. W. Reilly

November 1979

Prepared for the U.S. Department of Energy under Contract EY-76-C-06-1830

Pacific Northwest Laboratory Operated for the U.S. Department of Energy by Battelle Memorial Institute 
NOTICE

This report was prepared as an account of work sponsored by the United States Government. Neither the United States nor the Department of Energy, nor any of their employees, nor any of their contractors, subcontractors, or their employees, makes any warranty, express or implied, or assumes any legal liability or responsibility for the accuracy, completeness or usefulness of any information, apparatus, product or process disclosed, or represents that its use would not infringe privately owned rights.

The views, opinions and conclusions contained in this report are those of the contractor and do not necessarily represent those of the United States Government or the United States Department of Energy.

\author{
PACIFIC NORTHWEST LABORATORY \\ operated by \\ BATTELLE \\ for the \\ UNITED STATES DEPARTMENT OF ENERGY \\ Under Contract EY-76-C-06-1830
}
Printed in the United States of America Available from
National Technical Information Service United States Department of Commerce 5285 Port Royal Road Springfield, Virginia 22151

Price: Printed Copy \$ $\because$ Microfiche $\$ 3.00$

NTIS

- Pages Selling Price

$\begin{array}{lr}001-025 & \$ 4.00 \\ 026-050 & \$ 4.50 \\ 051-075 & \$ 5.25 \\ 076-100 & \$ 6.00 \\ 101-125 & \$ 6.50 \\ 126-150 & \$ 7.25 \\ 151-175 & \$ 8.00 \\ 176-200 & \$ 9.00 \\ 201-225 & \$ 9.25 \\ 226-250 & \$ 9.50 \\ 251-275 & \$ 10.75 \\ 276-300 & \$ 11.00\end{array}$


PNL -3191 .

UC-94b

\section{8}

THE ECONOMICS OF COMPRESSED

AIR ENERGY STORAGE EMPLOYING

THERMAL ENERGY STORAGE

S. C. Schulte

R. W. Reilly

November 1979

Prepared for

the U.S. Department of Energy

under Contract EY-76-C-06-1830

Pacific Northwest Laboratory

Richland, Washington 99352 


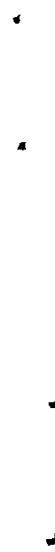




\section{FOREWORD}

The Compressed Air Energy Storage Technology Program at the Pacific Northwest Laboratory (PNL) is sponsored by the Department of Energy, Division of Energy Storage Systems. The program scope includes a group of studies directed at developing a new energy storage technology to improve the cost and efficiency of electrical power utilization and reducing the dependence on petroleum fuels such as oil and natural gas. The program has two major thrusts -.- Reservoir Stability Criteria Studies and Advanced Concepts Studies. These have the following objectives:

- Reservoir Stability Criteria Develop design and stability criteria for long-term operation of underground reservoirs used for compressed air energy storage (CAES) in order to accelerate the commercialization of the concept.

- Advanced Concepts Studies Develop and assess advanced CAES concepts that require little or no supplementary firing by petroleum fuels in order to eliminate the dependence of CAES on petroleum fuels.

The ultimate objective of this program is to reduce the consumption of natural gas and oil used for peak-power generation plants by about $100,000,000$ barrels per year. This could be accomplished by replacing conventional gas turbine peaking plants currently being used by utilities with CAES plants.

The following documents have been issued by PNL or by subcontractors to PNL, reporting the results of the work toward these objectives.

- Air Storage Peaking Power Plants Utilizing Modified Industrial Gas Turbines and Cavities with Nuclear Explosives, B.C. Fryer, BNWL-1748, May 1973.

- Technical and Economic Feasibility Analysis of the No-Fuel Compressed Air Energy Storage Concept, D.K. Kreid, BNWL-2065, May 1976. 
- FY-1977 Progress Report - Stability and Design Criteria Studies for Compressed Air Energy Storage Reservoirs, G.C. Smith, J.A. Stottlemyre, L.E. Wiles, W.V. Loscutoff and H.J. Pincus, PNL-2443 March 1978.

- FY-1977 Progress Report Compressed Air Energy Storage Advanced Systems Analysis, D.K. Kreid and M.A. McKinnon, PNL-2464, March 1978.

- Preliminary Stability Criteria for Compressed Air Energy Storage in Porous Media Reservoirs, J.A. Stottlemyre, PNL-2685, June 1978.

- Preliminary Long-Term Stability Criteria for Compressed Air Energy Storage Caverns in Salt Domes, R.L. Thoms and J.D. Martinez, PNL-2871, August 1978.

- Numerical Analysis of Temperature and Flow Effects in a Dry, OneDimensional Aquifer Used for Compressed Air Energy Storage, G. C. Smith, L.E. Wiles, and W.V. Loscutoff, PNL-2546, February 1979.

- The Effects of Water on Compressed Air Energy Storage in Porous Rock Reservoirs, L.E. Wiles, PNL-2869, March 1979.

- Pacific Northwest Laboratory Annual Report for 1978 to the DOE Division of Energy Storage Systems - Compressed Air Energy Storage Technology Program, W. V. Loscutoff, PNL-2935, June 1979.

- Incremental Cost Analys is of Advanced Concept CAES Systems, C.A. Knutsen, Knutsen Research Services, PNL-3118, September 1979.

- Numerical Analysis of Temperature and Flow Effects in a Dry, TwoDimensional, Porous-Media Reservoir Used for Compressed Air Energy Storage, L. E. Wiles, PNL-3047, October 1979. 


\section{EXECUTIVE SUMMARY}

Much of the energy-storage literature concludes that compressed air energy storage (CAES) is an economically feasible alternative to existing modes of peak-demand energy generation. These studies, however, employ various sets of assumptions and different analytical methodologies, making it difficult to compare the economics of the various CAES designs. This report provides an economic comparison of the systems proposed by several of the existing studies, thereby enabling an economic ranking of the several designs and establishing a degree of veracity for the studies. The approach taken in this study is to adopt system design and capital cost estimates from three independent CAES studies (eight total designs) and, by supplying a common set of fuel/energy costs and economic assumptions in conjunction with a common methodology, to arrive at a series of levelized energy costs over the system's lifetime. In addition, some analyses are provided to gauge the sensitivity of these levelized energy costs to fuel and compression energy costs and to system capacity factors.

The systems chosen for comparison are of four generic types: conventional CAES, hybrid CAES, adiabatic CAES, and an advanced-design gas turbine (GT). In conventional CAES systems the heat of compression generated during the storage operation is rejected to the environment, and later, during the energy-generation phase, turbine fuel must be burned to reheat the compressed air. In the hybrid systems some of the heat of compression is stored and reapplied later during the generation phase, thereby reducing turbine fuel requirements. The adiabatic systems store adequate thermal energy to eliminate the need for turbine fuel entirely. The gas turbine is included within the report for comparison purposes; it is an advanceddesign turbine, one that is expected to be available by 1985 .

In the analyses, a standard set of operating conditions is maintained and key economic inputs are varied to determine the economic performance of each of the systems over a range of possible future scenarios. Each of the plants is assumed to come on line in 1985 with a lifetime of 30 years. The fixed charge rate $(15 \%)$ and the discount factor $(10 \%)$ 
are assumed to be identical for each of the plants, as is the overall inflation rate $(6 \%)$. Major variables in the analysis are fuel cost and escalation rate, compression energy cost, and plant capacity factor.

Case 1 represents a "historical" 1978-based set of assumptions. Turbine fuel cost is assumed to be $\$ 3.33 / 10^{6} \mathrm{Btu}$, considerably below today's market price. The results show that the levelized costs of electricity from all of the generic designs are close. Conventional CAES is the least expensive $(93.7 \mathrm{mills} / \mathrm{kWh}$ ) and adiabatic CAES is the most expensive $(107.6 \mathrm{mills} / \mathrm{kWh})$. The gas turbine is very competitive under these conditions (104.6 mi11s/kWh).

The rankings change dramatically under present-day assumptions, Case 2, where a turbine fuel price of $\$ 5.00 / 10^{6}$ Btu is used and the fuel escalation rate is raised from $7 \%$ /year to $8 \% /$ year. In this case the adiabatic design performs far better economically than do the other concepts. The adiabatically generated levelized cost of electricity is $91.1 \mathrm{mills} / \mathrm{kWh}$ while the next best system, the hybrid design, costs $108.8 \mathrm{mills} / \mathrm{kWh}$. The high cost of turbine fuel raises the gas turbine to a levelized cost of $174.6 \mathrm{mills} / \mathrm{kWh}$.

If a high cost of compression energy is assumed along with the 1979 fuel prices, (Case 3 ), the three CAES systems are grouped together at about $140 \mathrm{mills} / \mathrm{kWh}$. The gas turbine system is still more expensive than the rest, but only by a factor of $27 \%$.

Finally, if the 1979 assumptions are made while employing a low capacity factor ( $12 \%$ rather than the $24 \%$ used in the other cases), the rankings remain unchanged, but the adiabatic design loses much of its former economic advantage. Its levelized cost of electricity is 130.9 $\mathrm{mills} / \mathrm{kWh}$ versus $137.3 \mathrm{mills} / \mathrm{kWh}$ for the nearest competitor, conventional CAES.

It should be noted that the levelized cost of electricity attributed to each technology represents an average of the calculated costs for several specific designs. This is not a bad assumption for conventional and 
hybrid CAES since the costs resulting from individual designs within a single technology are relatively close to one another. It is, however, a major problem for adiabatic CAES where there is a considerable difference in the levelized cost of electricity produced by the two system designs. More work needs to be done to explain this difference.

The following conclusions are made with respect to the economic performance of compressed air energy storage systems:

- The economic ranking of conventional CAES, hybrid CAES, adiabatic CAES, and gas turbines for the generation of peak-demand electrical power is highly dependent upon fuel oil prices and compression energy costs.

- Given today's fuel oil prices, CAES systems appear to enjoy tremendous cost savings over the more traditional gas turbine systems for a wide range of systems applications and compression energy costs.

- Given today's fuel oil prices, adiabatic systems appear to be slightly more economical than conventional CAES systems.

- The estimating procedures for advanced CAES technology need to be more systematized to enable comparisons of different designs and identification of most promising candidates. 


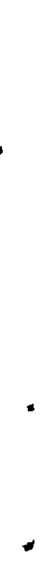




\section{CONTENTS}

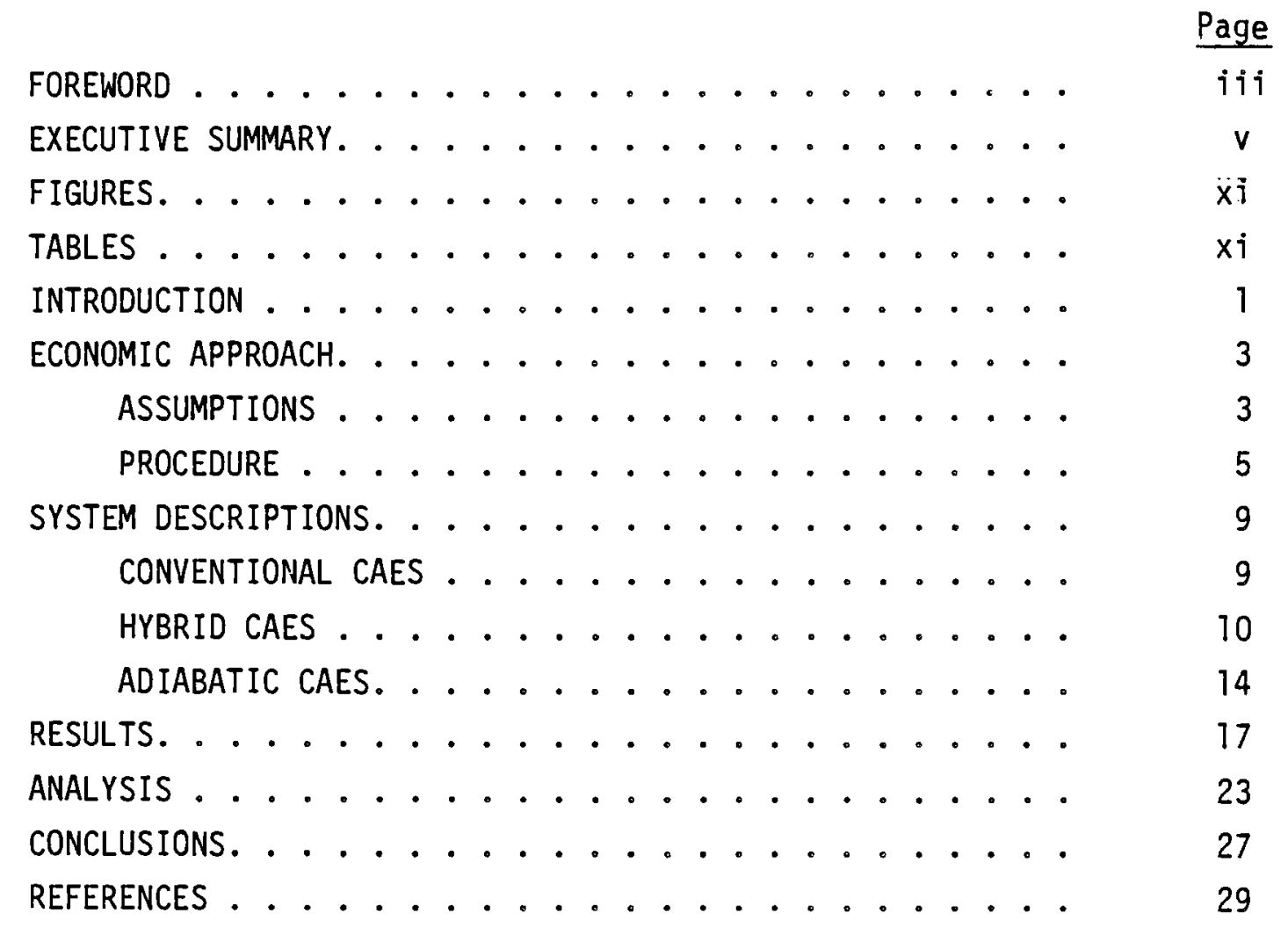




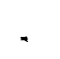

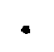




\section{FIGURES}

$\begin{array}{lll}1 & \text { Schematic for CONV/CEGB Conventional CAES Design. . . . . } 11 \\ 2 & \text { Schematic for CONV/KNUT Conventional CAES Design. . . . . } 11 \\ 3 & \text { Schematic for HYBR/KN- H Hybrid CAES Design. . . . . . . } 12 \\ 4 & \text { Schematic for HYBR/KN-4 Hybrid CAES Design. . . . . . . } 12 \\ 5 & \text { Schematic for HYBR/CEGB Hybrid CAES Design. . . . . . . } 13 \\ 6 & \text { Schematic for ADIAB/KNU Adiabatic CAES Design . . . . . } 15 \\ 7 & \text { Schematic for ADIAB/MIT Adiabatic CAES Design . . . . . . } 15\end{array}$

\section{TABLES}

1 Input Assumptions for Each Analysis . . . . . . . . . 4

2 System Descriptions . . . . . . . . . . . . 6

3 Levelized Cost of Electricity (mills/kWh, 1979 Price Leve1) - 1. 1978-Based Assumptions. . . . . . . 18

4 Levelized Cost of Electricity (mills/kWh, 1979 Price Leve1) - 2. 1979-Based Assumptions (Base Case). . . 19

5 Levelized Cost of Electricity (mills/kWh, 1979 Price Levels) - 3. High Compression Energy Cost Assumption. ................ 20

6 Levelized Cost of Electricity (mills/kWh, 1979 Price Levels) - 4. Low Capacity Factor Assumption . . . . . 22

7 Summary of System Capital Costs in a per-kilowatt

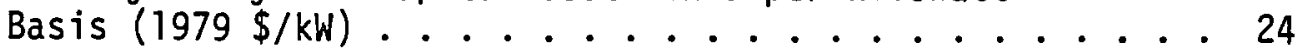




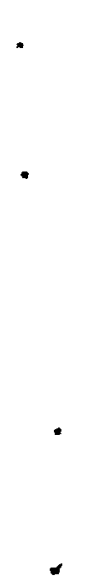


INTRODUCTION

Compressed Air Energy Storage (CAES) is a method of storing low-cost electrical energy available during times of low demand for use during periods of peak electrical demand to reduce the need for high-cost peaking capacity. This is accomplished by using excess baseload generating capacity available at night and on weekends to compress and store air in underground reservoirs. When peaking capacity is required, the compressed air is expanded in turbines to generate electricity. In gas turbines used for peak power generation, about two-thirds of the turbine's output is utilized to power its own compressor. In the CAES cycle, all of the turbine's output is available to meet demand since the compression work is accomplished during the storage mode. Thus, there are two major advantages to the CAES system: 1) the turbine will produce up to three times the electrical power for the same amount of petroleum fuel, and 2) the energy required for compression costs less because it is furnished by low-cost baseload capacity rather than by expensive peaking capacity. The trade-off, of course, is the added cost of the CAES reservoir.

A major obstacle to commercialization of the CAES concept may be $i$ ts reliance upon petroleum fuels. A number of advanced CAES systems have been proposed to overcome the obstacle. One of the more promising designs captures and stores the heat of compression for reapplication to the compressed air during the expansion phase. This thermal storage is generally realized by channelling the hot compressed air through a packed pebble bed (or similar thermal storage device) prior to cavern storage, and then by discharging the air back through the pebble bed to recover the heat of compression before expansion in the turbine. These advanced CAES systems with thermal energy storage (CAES/TES) are termed adiabatic if sufficient heat of compression is available during the expansion phase to eliminate totally the need for turbine fuel; they are termed hybrid if the need for turbine fuel is reduced, but not eliminated, by TES. 
The objective of this report is to compare the cost of generating electricity from CAES/TES systems to the cost from conventional CAES systems and gas turbine (GT) systems. Eight different designs are considered: two conventional, three hybrid, two adiabatic, and one gas turbine. These designs were selected from the available literature using two selection criteria: 1) the designs had to be near term (available by 1985), and 2) where a choice was possible, the system with the best economic performance was selected. The three sources for the designs (Glendenning 1979, Flynn and Nash-Webber 1979, and Knutsen 1979) all present economic analyses, but a straight-on comparison of the systems is impossible because of differences in assumptions and methodologies. The approach in this report is to adopt system design and capital cost estimates from the original sources and, by supplying common financial, economic, and resource cost assumptions to a common methodology, to compare economic performance of the systems. The measure of economic performance is system energy cost levelized over the system's operating lifetime. The cost estimates are reported in 1979 price levels in terms of mills/kWh. 


\section{ECONOMIC APPROACH}

The methodology employed to estimate levelized energy cost is taken from the EPRI Technical Assessment Guide (1978) since that document is the generally accepted handbook for large-scale energy system cost calculations. System costs are divided into four categories: capital expenditures, fuel costs, compression energy costs, and operations and maintenance. Each of these individual cost elements is levelized over the system's operating lifetime, and then these individual levelized costs are summed to generate the system's levelized cost of electricity, a surrogate for overall economic performance. "Levelizing" is the process of assigning a cost value that remains constant each year of system operation. This value is calculated such that the sum of the present values of these levelized costs over the system's lifetime is exactly equal to the sum of the present values of the actual costs that would be incurred by the system over its lifetime.

\section{ASSUMPTIONS}

In general, the assumptions used in these analyses, listed in Table 1 , are those recommended by EPRI (1978). One major deviation from these recommendations is the price of turbine fuel. The EPRI estimate for 1979 is $\$ 3.33 /$ million Btu, well below present market rates; it is used for one illustration (Case 1) in order to show how the systems would have compared one to two years ago when oil prices were lower. For the balance of the calculations, however, an updated cost of $\$ 5 / \mathrm{million}$ Btu is employed. In concert with this train of thought, a fuel price escalation rate of $8 \% /$ year is used rather than the EPRI-recommended $7 \%$ /year.

Four sets of calculations are performed in order to gauge the relative economic performance of the designs under varying conditions:

- Case 1 is the "historic" case, which looks at the situation as it might have been viewed in 1978 . 
TABLE 1. Input Assumptions for Each Analysis

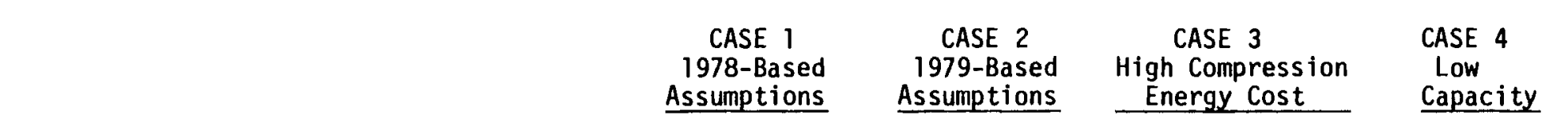

Plant-Descriptive Assumptions

First Year of Plant Operation

Plant Capacity Factor

operating Life (years)

-(a)

$-$

$-$

$-$

$-$

20

3.33

Compression Energy Cost (mills/kWh)

Turbine Fuel Cost $\left(\$ / 10^{6}\right.$ Btu)

Escalation Rate Assumptions

General Inflation Rate (\%/yr)

Escalation Rate for Capital Equipment (\%/yr)

Escalation Rate for Operations and Maintenance (\%/yr)

Escalation Rate for Compression Energy (\%/yr)

Escalation Rate for Turbine Fuel $(\% / y r)$

(a) dash indicates that entry is identical to the Case 2 (1979-based) assumption. 
- Case 2 is the "base case" for the remainder of the calculations. It employs a moderate compression energy price of $15 \mathrm{mil1s} / \mathrm{kWh}$, which exists in many parts of the country for baseload generating capacity, and a $\$ 5$ turbine fuel price.

- Case 3 is identical to the base case except that it uses a moderately high compression energy cost of $30 \mathrm{mills} / \mathrm{kWh}$, typical of utilities with predominantly new baseload generating capacity.

- Case 4 is again identical to the base case, with one exception, that system capacity factor is reduced. In the previous cases the systems are assumed to generate electricity 8 hours per day, five days per week, for a $24 \%$ capacity factor. In Case 4 this capacity factor is reduced to $12 \%$, just over 4 hours per day per five day week.

\section{PROCEDURE}

Three pieces of data are extracted from the source reports for each of the systems under investigation: the fuel heat rate, the coefficient of performance, and the estimated capital investment. These data are listed in Table 2. Normalized cost estimates are then made for each of the systems in each of four cost categories: capital investment, fuel, compression energy, and operations and maintenance ( 0 \& $M$ ) over the system's lifetime.

The capital investment estimates are normalized in a multistep process. First interest and escalation-during-construction costs supplied by the authors are removed from system estimates. Next each of the estimates is brought to a mid-1979 price level using a 10\% escalation rate to represent the high rate of inflation experienced in the last few years. Finally, interest and escalation-during-construction costs are reapplied on a common basis using a $61 / 2$ year construction period.

Fuel costs are estimated from the fuel heat rates supplied by the authors of the respective reports; compression energy costs are estimated 
TABLE 2. System Descriptions

\begin{tabular}{|c|c|c|c|c|c|c|}
\hline $\begin{array}{c}\text { System } \\
\text { Designation } \\
\end{array}$ & $\begin{array}{l}\text { Reference } \\
\text { Study }\end{array}$ & $\begin{array}{c}\text { Reference Study } \\
\text { Designation } \\
\end{array}$ & $\begin{array}{l}\text { Puel Heat } \\
\text { Rate } \\
\text { (Btu/kWh) }\end{array}$ & $\left(k W h_{\text {out }}^{\text {COP }} / k W h_{\text {in }}\right)$ & $\begin{array}{l}\text { Capital } \\
\text { Inves tment } \\
\text { (1979 \$/kW) } \\
\end{array}$ & $\begin{array}{c}\text { Design } \\
\text { Output } \\
\text { (MW) } \\
\end{array}$ \\
\hline \multicolumn{7}{|c|}{ Conventional Systems } \\
\hline CONV/CEGB & CEGB & $\begin{array}{l}\text { 2nd Generation } \\
\text { Brown Boveri }\end{array}$ & 4078 & 1.2 & 266 & 220 \\
\hline CONV/KNUT & Knutsen & Reference & 4408 & 1.45 & 292 & 750 \\
\hline \multicolumn{7}{|l|}{ Hybrid Systems } \\
\hline HYBR/KN-1 & Knutsen & TES-1 & 4068 & 1.31 & 344 & 750 \\
\hline HYBR/KN-4 & Knutsen & TES -4 & 3540 & 1.13 & 356 & 750 \\
\hline HYBR/CEGB & CEGB & $\begin{array}{l}\text { A5-hybrid, J-13, } \\
\text { Case } 1\end{array}$ & 2641 & 0.95 & 304 & 275 \\
\hline \multicolumn{7}{|c|}{ Adiabatic Systems } \\
\hline$A D I A B / K N U$ & Knutsen & TES - 3 & 0 & 0.65 & 581 & 750 \\
\hline ADIAB/MIT & MIT & G & 0 & 0.71 & 317 & 267 \\
\hline \multicolumn{7}{|l|}{ Gas Turbines } \\
\hline GT & GT & Knutsen/TAG & 11,500 & $N / A$ & 185 & 750 \\
\hline
\end{tabular}

*These system designations are defined on pages 9 and 15 . 
from the coefficients of performance (COPs) supplied by the authors. An identical 0 \& $M$ estimate is made for each of the systems. Although there is no field experience with these technologies (except for the plant at Huntorf, Germany), 0 \& $M$ costs should be fairly constant on a per-kilowatt basis, and any differences in the analytical results due to errors in the 0 \& $M$ estimates should be negligible. All cost estimates are converted to a per-kilowatt-hour basis by dividing them by the system's rated capacity; these costs (in mills/kWh) are then levelized over the system's lifetime using the EPRI-recommended methodology. Finally, all estimates are expressed in 1979 price levels, and the four component costs are added to generate a levelized system cost, which is used as a measure of the system's economic performance. The cost estimates for the gas turbine are made in a similar manner, but installation of the unit is estimated to take only one year. 


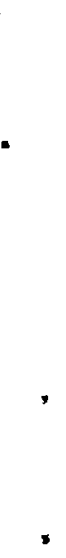




\section{SYSTEM DESCRIPTIONS}

The three generic CAES systems analyzed in this paper (conventional, hybrid, and adiabatic) are described below, along with more specific descriptions of the actual design selected for economic comparison. The gas turbine system used for comparison in the analysis is not taken from a specific design study but rather from a set of parameters for turbine systems as suggested by the Technical Assessment Guide (EPRI 1978).

Many of the design basics are common to all of the CAES systems. For instance, all hardrock-mined caverns for compressed air storage are hydrostatically compensated. Furthermore, all have storage sized to enable at least 8 hours of continuous electricity generation, although some storage capacities are larger. Each of the system designs utilizes a near term technology and could be put into operation by 1985 .

\section{CONVENTIONAL CAES}

A CAES installation consists of four main components: a compressor, a motor/generator, a combustion turbine, and an air storage unit. It is operated in two distinct modes: charging (or storage) and discharging (or power generation). In the charging mode low-cost electrical energy available from baseload capacity during times of low demand is used to drive the compressor, thereby storing compressed air (after cooling) in the underground storage chambers. Then, during periods of peak electrical demand, the process is reversed and the discharge operation is employed to generate electricity by expanding the compressed air in a combustion turbine. Since the air is cooled between the compression and storage phases in order to permit efficient storage, it needs to be reheated before it can be effectively expanded in the turbine. Generally this is accomplished by the combustion of a petroleum fuel. One advantage to the CAES technology is its versatility: properly designed, a CAES turbine system can function as a conventional gas turbine (although at only one-half to one-third of its rated output) when its compressed air supply is exhausted. 
Two conventional CAES plant designs were selected for inclusion in this study. The first was prepared for the Electric Power Research Institute (EPRI) by the Central Electricity Generating Board (Glendenning 1979); it is designated as CONV/CEGB throughout the analysis. It is a second generation CAES system modeled on the Brown Boveri installation in Huntorf, Germany. However, there is one major difference: the CONV/CEGB employs a heat recuperator to recycle waste turbine exhaust heat to preheat incoming compressed air while the Huntorf design has no recuperator. The CONV/CEGB is shown in Figure 1.

The second conventional design (CONV/KNUT) (Knutsen 1979) is a product of a study done by Knutsen Research Services for PNL. (See Figure 2.) It is conceptually similar to the CEGB system; however, one of the main differences is that the storage capacity is sized for 20 hours to allow for stockpiling of compressed air over weekends to meet heavy weekday loads.

HYBRID CAES

In the hybrid systems, CAES is coupled to thermal energy storage for the purpose of reducing system fuel requirements. The plant's operation is similar to a conventional CAES installation except that, after compression, some of the heat is captured and stored rather than discarded. Then, when the compressed air is released to drive the turbine, it is reheated using the stored heat, thereby reducing the amount of fossil fuel that must be fired to heat the compressed air to the temperatures required by the turbines. Three different hybrid configurations are selected for analysis: two from knutsen (1979) and one from the CEGB report (Glendenning 1979). The major design differences lie in placement of the TES unit. The HYBR/KN-1 (Knutsen) design locates the TES unit in the high pressure stage; in the HYBR/KN-4 (Knutsen) and the HYBR/CEGB (CEGB) designs, the TES chambers are located in the intermediate pressure stage. As in the conventional designs, the HYBR/CEGB calls for 8 hours storage and the Knutsen units are designed for 20 hours of storage. These three designs are depicted in Figures 3, 4 and 5 . 


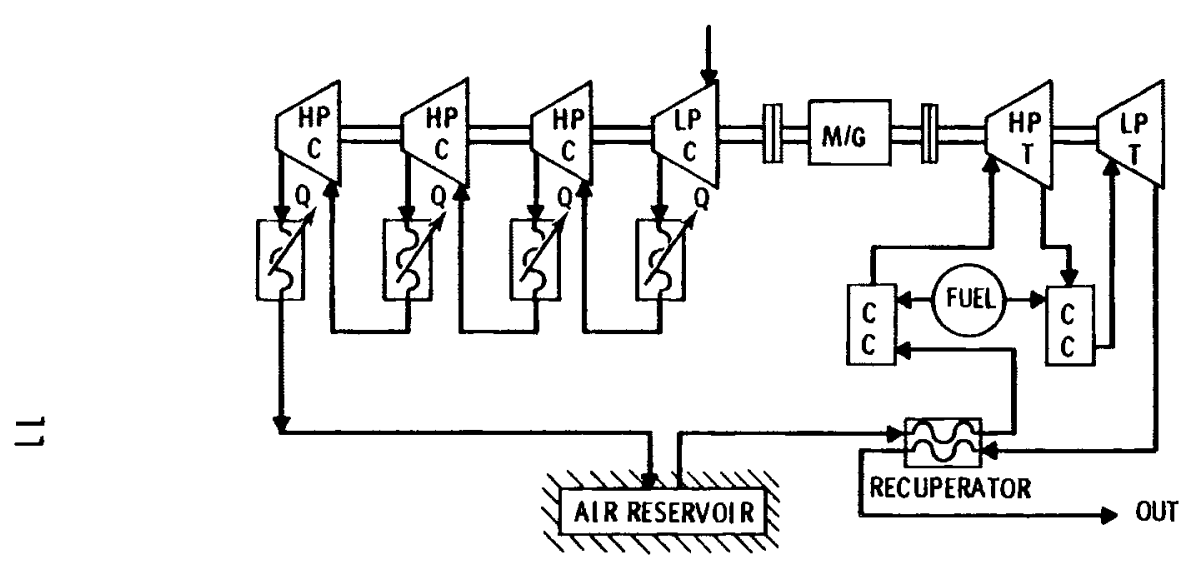

FIGURE 1. Schematic for CONV/CEGB Conventional CAES Design

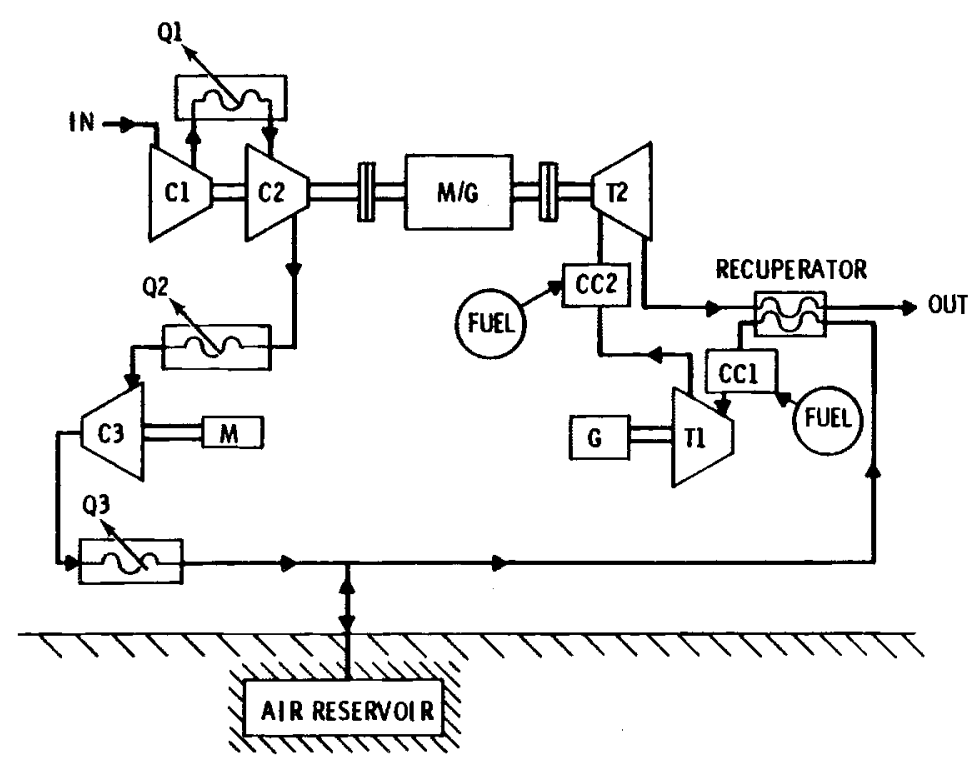

FIGURE 2. Schematic for CONV/KNUT Conventional CAES Design 


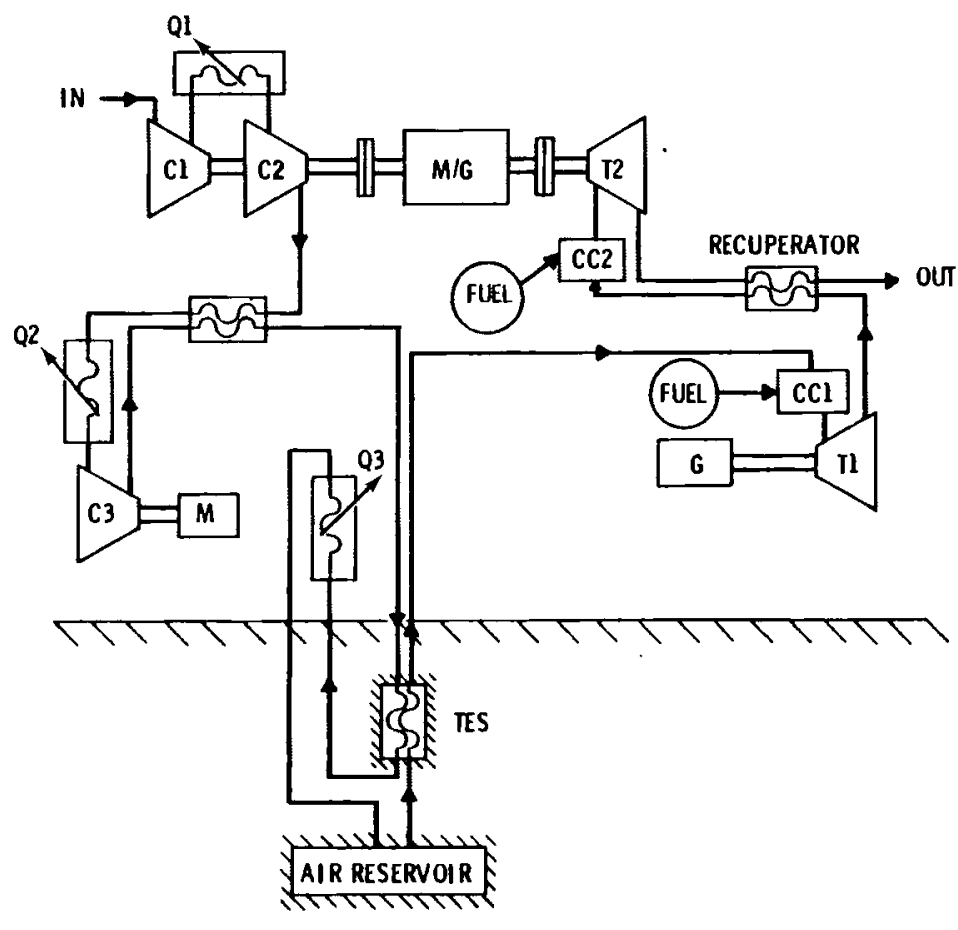

FIGURE 3. Schematic for HYBR/KN-1 Hybrid CAES Design

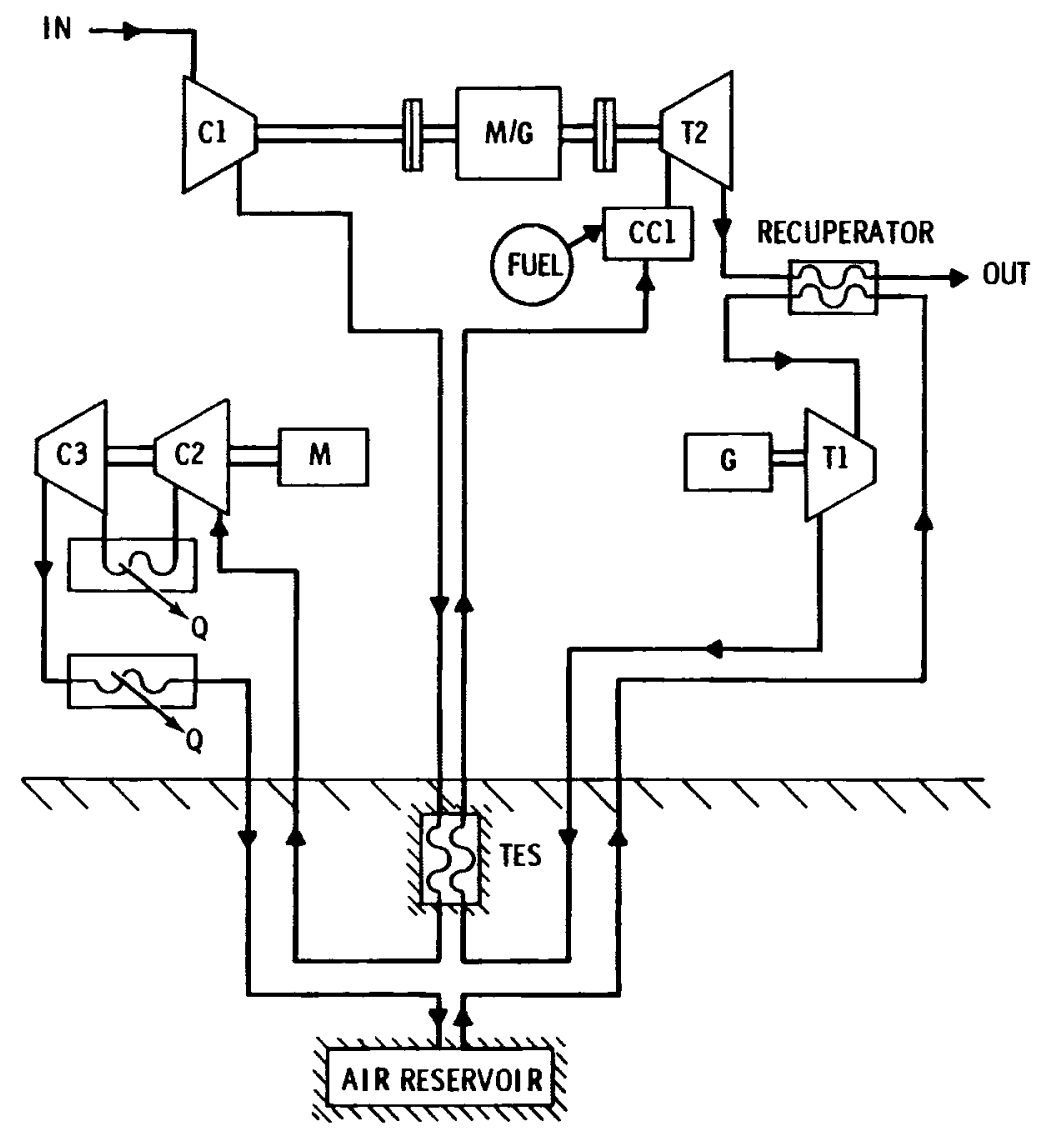

FIGURE 4. Schematic for HYBR/KN-4 Hybrid CAES Design 


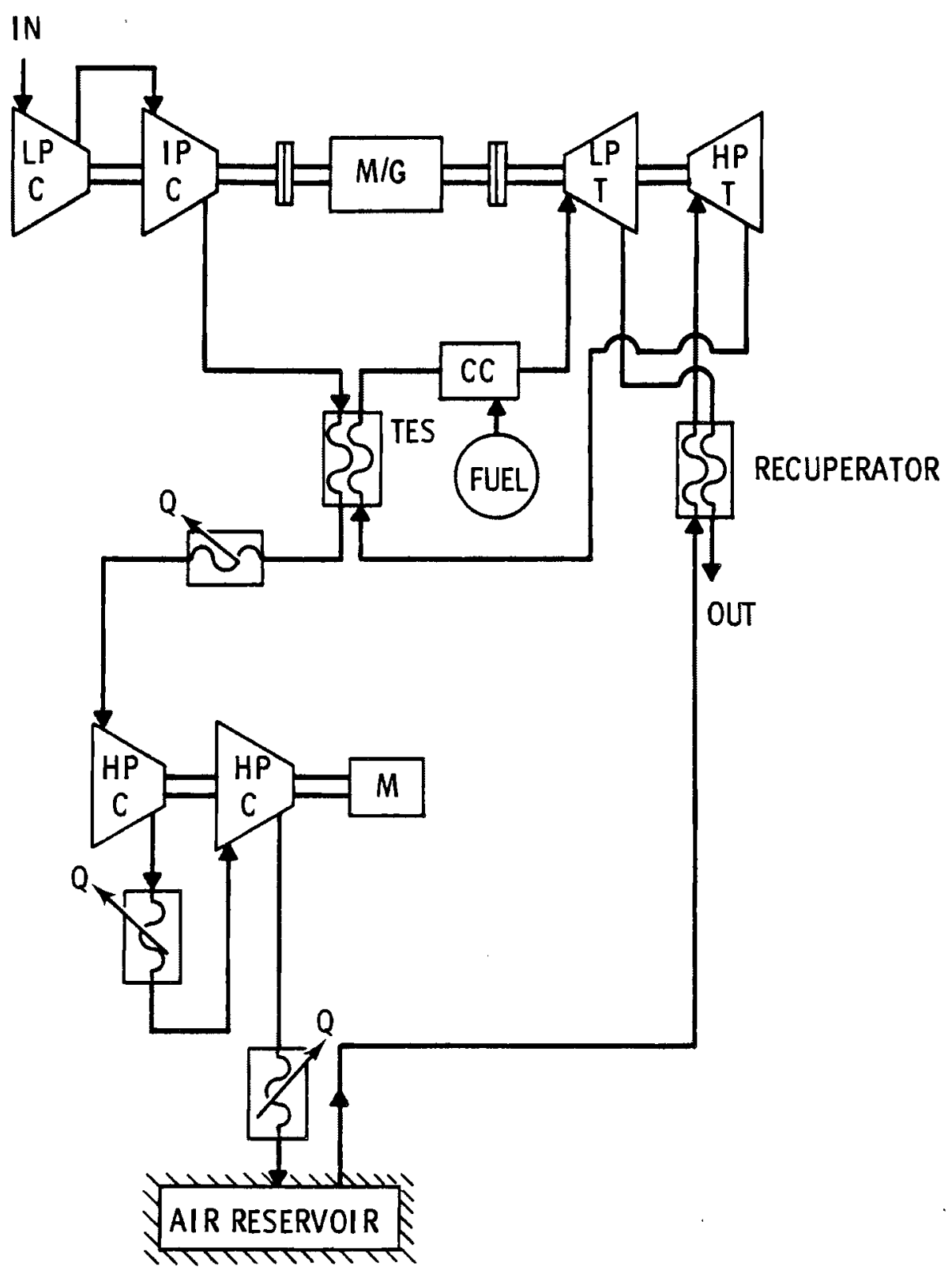

FIGURE 5. Schematic for HYBR/CEGB Hybrid CAES Design 


\section{ADIABATIC CAES}

In the adiabatic CAES systems, adequate thermal energy is stored and recovered by the compressed air before expansion to allow operation of the turbines without fuel combustion. Generally at least a two-stage TES design is required to effect such a capability. Two adiabatic systems were selected for economic analysis: one from the Knutsen paper (Knutsen 1979), and one from a paper currently being done by the Massachusetts Institute of Technology for the Department of Energy by G.T. Flynn and J.L. Nash-Webber. The Knutsen design ( $A D I A B / K N U$ ) shown in Figure 6 , is similar in output capacity and storage design to the other Knutsen designs. The MIT design (ADIAB/MIT), shown in Figure 7 , is the most cost effective of a large number of designs analyzed in that paper. It is sized for 8 hours of storage. 


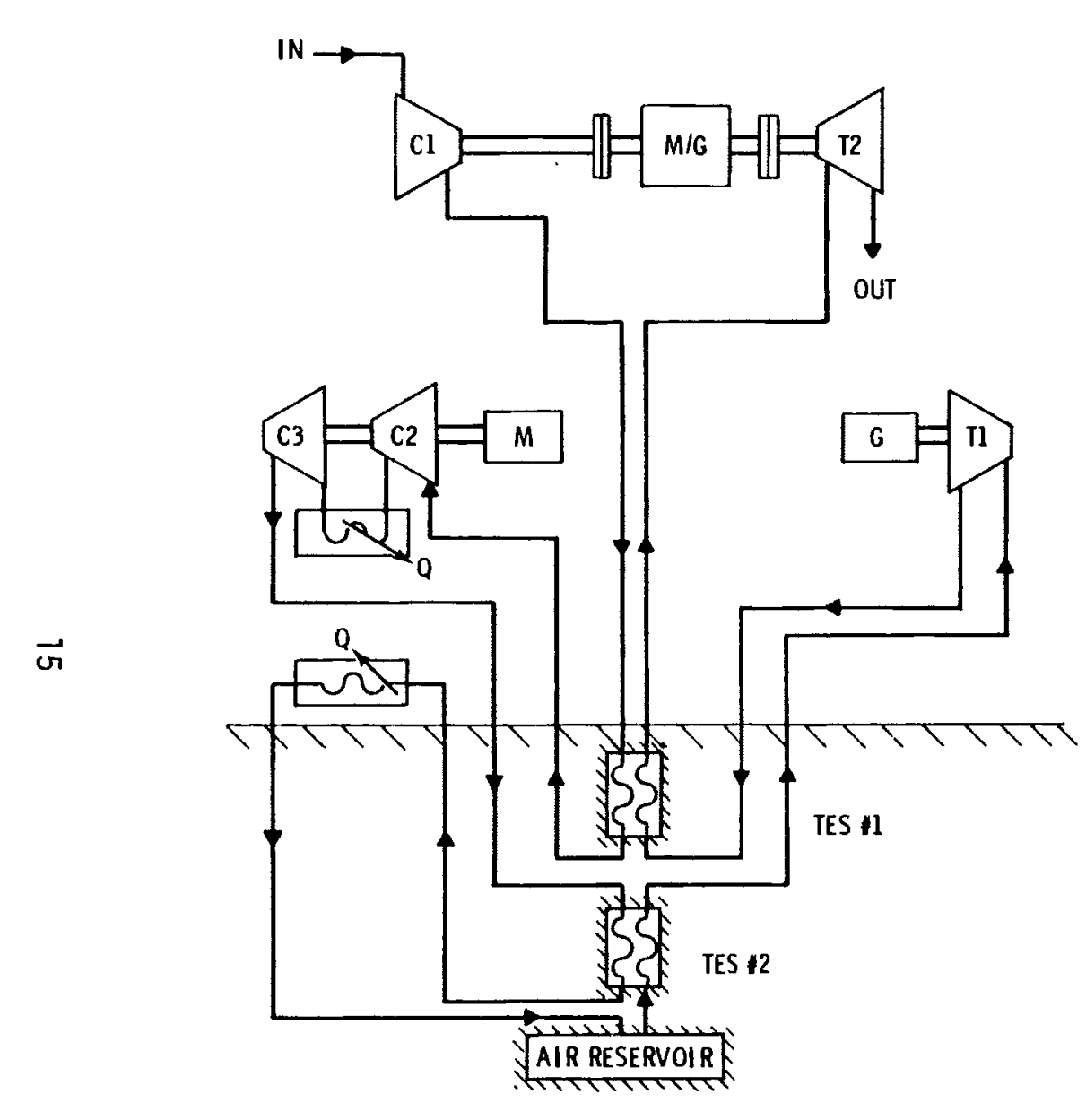

FIGURE 6. Schematic for ADIAB/KNU Adiabatic CAES Design

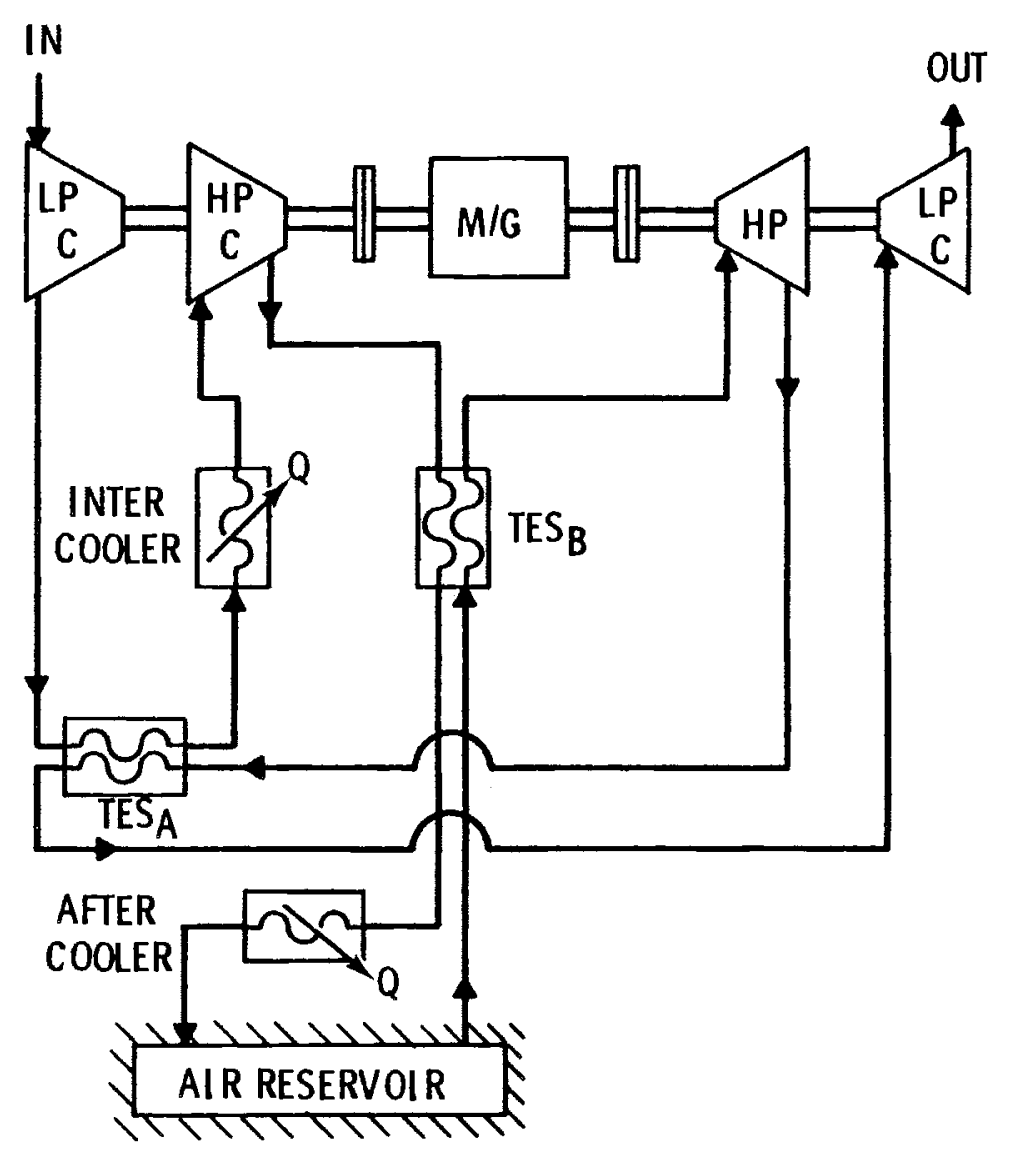

FIGURE 7. Schematic for ADIAB/MIT Adiabatic CAES Design 
. 


\section{RESULTS}

Case 1 (the 1978-based assumptions) uses a turbine fue1 cost that is considerably lower than today's market price. It is included to indicate the rankings that would have been developed had this comparative analysis been performed before the most recent round of fuel price escalations. The results of this analysis show that the levelized costs of electricity from all of the generic designs are close; conventional CAES is the least expensive and adiabatic CAES is the most expensive. The results are listed in Table 3. Under these assumptions, the savings in fuel expenditures over the life of the hybrid and adiabatic systems are inadequate to recover the additional capital cost necessary to construct the thermal storage systems.

The rankings change dramatically when the more recent 1979 fuel costs are entered into the calculations. The adiabatic CAES systems rank first by a rather large margin; the hybrid and conventional CAES systems are very close in the middle; and the gas turbine lags far behind at almost twice the cost of the adiabatic system. (See Table 4.) Under these conditions, fuel accounts for nearly half of total levelized cost of the conventional systems and for a large fraction of the levelized cost of the hybrid systems, which gives the adiabatic systems a significant advantage. Any fuel escalations beyond the $8 \% /$ year assumed in Case 2 would, of course, further enhance the attractiveness of the adiabatic sys tems.

If a high cost for compression energy is assumed along with the 1979 fuel prices (Case 3, Table 5), the three CAES systems are grouped together, with conventional CAES enjoying a slight advantage. The GT remains more expensive than the rest, although it is on $1 y 27 \%$ more expensive than the least-cost system. It is apparent from this analysis that the selection of a generic CAES system for a particular utility installation may be highly dependent upon the cost of generating baseload electricity. 
TABLE 3. Levelized Cost of Electricity (mills/kWh, 1979 Price Level)

Case 1. 1978-Based Assumptions

\begin{tabular}{|c|c|c|c|c|c|c|c|c|c|}
\hline & & CONV/CEGB & CONV/KNUT & HYBR/KN-1 & HYBR/KN-4 & HYBR/CEGB & ADIAB/KNU & ADIAB/MIT & $\underline{G T}$ \\
\hline & Capital Investment & 21.5 & 23.5 & 27.7 & 28.7 & 24.5 & 46.9 & 25.6 & 13.3 \\
\hline & Fuel & 30.6 & 33.1 & 30.5 & 26.6 & 19.8 & 0.0 & 0.0 & 86.3 \\
\hline & Compression Energy & 37.5 & 31.1 & 34.4 & 39.9 & 47.4 & 69.3 & 63.4 & 0.0 \\
\hline & Operation \& Maintenance & 5.0 & 5.0 & 5.0 & 5.0 & 5.0 & 5.0 & 5.0 & 5.0 \\
\hline & Total & 94.6 & 92.7 & 97.6 & 100.2 & 96.7 & 121.2 & 94.0 & 104.6 \\
\hline & & \multicolumn{2}{|c|}{ Conventional } & \multicolumn{3}{|c|}{ Hybrid } & \multicolumn{2}{|c|}{ Adiabatic } & $\underline{G T}$ \\
\hline & $\begin{array}{l}\text { Average Cost for } \\
\text { each Technology }\end{array}$ & \multicolumn{2}{|c|}{93.7} & \multicolumn{3}{|c|}{98.2} & \multicolumn{2}{|c|}{107.6} & 104.6 \\
\hline & Economic Ranking & \multicolumn{2}{|r|}{1} & \multicolumn{3}{|c|}{2} & \multicolumn{2}{|c|}{4} & 3 \\
\hline
\end{tabular}

ASSUMPTIONS: capacity factor: (\%/year) 24

compression energy cost (mills/kwh) 20

turbine fuel cost (\$/million Btu) $\quad 3.33$

turbine fuel escalation rate $(\% / y r)$ ? 
TABLE 4. Levelized Cost of Electricity (mil1s/kWh, 1979 Price Level) Case 2. 1979-Based Assumptions (Base Case)

\begin{tabular}{|c|c|c|c|c|c|c|c|c|}
\hline & CONV/CEGB & CONV/KNUT & HYBR/KN-1 & HYBR/KN-4 & HYBR/CEGB & $\underline{A D I A B / K N U}$ & ADIAB/MIT & $\underline{G T}$ \\
\hline Capital Investment & 21.5 & 23.5 & 27.7 & 28.7 & 24.5 & 46.9 & 25.6 & 13.3 \\
\hline Fuel & 55.4 & 59.9 & 55.3 & 48.1 & 35.9 & 0.0 & 0.0 & 156.3 \\
\hline Compression Energy & 28.2 & 23.3 & 25.8 & 29.9 & 35.6 & 52.0 & 47.6 & 0.0 \\
\hline Operation \& Maintenance & 5.0 & 5.0 & 5.0 & 5.0 & 5.0 & 5.0 & 5.0 & 5.0 \\
\hline Total & 110.1 & 111.7 & 113.8 & 111.7 & 101.0 & 103.9 & 78.2 & 174.6 \\
\hline
\end{tabular}

Conventional

110.9
Hybrid

108.8
Adiabatic

91.1

GT

Each Technology

$\vec{\emptyset}$

ASSUMPTIONS: capacity factor (\%/year)

compression energy cost (mills/kWh)

turbine fuel cost $(\$ / m i l l i o n$ Btu) 
TABLE 5. Levelized Cost of Electricity (mills/kWh, 1979 Price Levels) Case 3. High Compression Energy Cost Assumption

\begin{tabular}{|c|c|c|c|c|c|c|c|c|}
\hline & CONV/CEGB & CONV/KNUT & HYBR/KN-1 & HYBR/KN-4 & HYBR/CEGB & ADIAB/KNU & ADIAB/MIT & $\underline{\text { GT }}$ \\
\hline Capital Investment & 21.5 & 23.5 & 27.7 & 28.7 & 24.5 & 46.9 & 25.6 & 13.3 \\
\hline Fuel & 55.4 & 59.9 & 55.3 & 48.1 & 35.9 & 0.0 & 0.0 & 156.3 \\
\hline Compression Energy & 56.3 & 46.6 & 51.6 & 59.8 & 71.1 & 104.0 & 95.2 & 0.0 \\
\hline Operations \& Maintenance & 5.0 & 5.0 & 5.0 & 5.0 & 5.0 & 5.0 & 5.0 & 5.0 \\
\hline Total & $\overline{138.2}$ & $\overline{135.0}$ & $\overline{139.6}$ & $\overline{141.6}$ & 136.5 & 155.9 & 125.8 & 174.6 \\
\hline & \multicolumn{2}{|c|}{ Conventional } & \multicolumn{3}{|c|}{ Hybrid } & \multicolumn{2}{|c|}{ Adiabatic } & GI \\
\hline $\begin{array}{l}\text { Average Cost for } \\
\text { Each Technology }\end{array}$ & \multicolumn{2}{|c|}{136.6} & \multicolumn{3}{|c|}{139.2} & \multicolumn{2}{|c|}{140.9} & 174.6 \\
\hline Economic Rakning & \multicolumn{2}{|r|}{1} & \multicolumn{3}{|c|}{2} & \multicolumn{2}{|c|}{2} & 4 \\
\hline
\end{tabular}

$\begin{array}{lll}\text { ASSUMPTIONS: } & \text { capacity factor: (\%/year) } & 24 \\ & \text { compression energy cost (mills/kWh) } & 30 \\ \text { turbine fuel cost (\$/million Btu) } & 5.00 \\ & \text { turbine fuel escalation rate (\%/year) } & 8\end{array}$


Finally, if the base case assumptions are modified with a low capacity factor (Case 4, Table 6), the rankings do not change. The adiabatic system loses a large portion of its economic advantage since its relatively high capital cost must be amortized over fewer hours of operation over system lifetime. 
TABLE 6. Levelized Cost of Electricity (mills/kWh, 1979 Price Leve1s)

Case 4. Low Capacity Factor Assumption

\begin{tabular}{|c|c|c|c|c|c|c|c|c|}
\hline & CONV/CEGB & CONV/KNUT & HYBR/KN-1 & HYBR/KN-4 & HYBR/CEGB & ADIAB/KNU & ADIAB/MIT & $\underline{G T}$ \\
\hline Capital Investment & 42.5 & 46.7 & 55.0 & 56.9 & 48.6 & 92.9 & 50.7 & 26.4 \\
\hline Fuel & 55.4 & 59.9 & 55.3 & 48.1 & 35.9 & 0.0 & 0.0 & 156.3 \\
\hline Compression Energy & 28.2 & 23.3 & 25.8 & 29.9 & 35.6 & 52.0 & 47.6 & 0.0 \\
\hline Operations \& Maintenance & 9.3 & 9.3 & 9.3 & 9.3 & 9.3 & 9.3 & 9.3 & 9.3 \\
\hline Total & 135.4 & 139.2 & 145.4 & 144.2 & 129.4 & 154.2 & 107.6 & 192.0 \\
\hline & \multicolumn{2}{|c|}{ Conventional } & \multicolumn{3}{|c|}{ Hybrid } & \multicolumn{2}{|c|}{ Adiabatic } & $\underline{G T}$ \\
\hline $\begin{array}{l}\text { Average Cost for } \\
\text { Each Technology }\end{array}$ & \multicolumn{2}{|c|}{137.3} & \multicolumn{3}{|c|}{139.7} & \multicolumn{2}{|c|}{130.9} & 192.0 \\
\hline Economic Ranking & \multicolumn{2}{|c|}{2} & \multicolumn{3}{|c|}{2} & \multicolumn{2}{|c|}{1} & 4 \\
\hline
\end{tabular}

$\begin{array}{lll}\text { ASSUMPTIONS: } & \text { capacity factor: (\%/year) } & 12.0 \\ \text { compression energy cost (mills } / \mathrm{kWh}) & 15 \\ \text { turbine fuel cost (\$/million Btu) } & 5.00 \\ \text { turbine fuel escalation rate (\%/year) } & 8\end{array}$ 


\section{ANALYSIS}

One of the major problems encountered in an analys is of this nature is the difficulty in obtaining comparable systems. This problem is felt acutely in this study since there are few economic analyses of CAES systems beyond the included studies, and there are some gross differences between the included studies that could not be easily eliminated. Two major differences between the designs are the rated output and the compressed air storage capacity.

The Knutsen designs are rated at $750 \mathrm{MW}$ while the remainder of the analyses are conducted on systems in the $250 \mathrm{MW}$ range. This difference is treated in this report by using a per-kilowatt of capacity basis for estimation of capital costs. Unfortunately, such treatment ignores economies of scale, but there is insufficient information within the studies to enable these economies to be factored out.

The second problem is more serious, al though the final conclusions of the study do not seem to be jeopardized. The capital cost estimates for the Knutsen studies are for 20 hours of compressed air storage while the remainder of the system designs specify only 8 hours of storage. This bias within the data is evident from a perusal of the capital investment estimates data (Table 7).

In both the conventional and hybrid systems the capital cost estimates are very close for each generic design, with some of the small differences between the estimates ascribable to differences in storage capacity. The estimates for the two adiabatic systems, however, are not close, and this difference cannot be attributed to differences in storage capacity and/or scale. Rather, the difference must lie in design or in methods of cost estimation. The $A D I A B / K N U$ cost estimate is $83 \%$ higher than the ADIAB/MIT estimate on a per-kilowatt of capacity basis. If the MIT estimate were used as the representative for adiabatic systems throughout the analysis, adiabatic systems would have been by far the best economic performers under all assumptions. On the other 
TABLE 7. Summary of System Capital Costs in a per-kilowatt Basis $(1979 \$ / \mathrm{kW})$

\begin{tabular}{|c|c|c|c|c|c|c|c|c|}
\hline Category & CONV/CEGB & CONV/KNUT & HYBR/KN-1 & HYBR/KN-4 & HYBR/CEGB & ADIAB/KNU & ADIAB/MIT & $\underline{G T}$ \\
\hline $\begin{array}{l}\text { Land, structure } \\
\text { and plant equipment }\end{array}$ & 35 & 9 & 9 & 9 & 24 & 8 & 39 & N/A \\
\hline Air storage & 36 & 51 & 51 & 62 & 27 & 106 & 51 & 0 \\
\hline Thermal storage & 0 & 0 & 22 & 29 & 46 & 93 & 64 & 0 \\
\hline Turbomachinery & 141 & 145 & 162 & 153 & 145 & 216 & 121 & $N / A$ \\
\hline $\begin{array}{l}\text { Electrical and } \\
\text { miscellaneous }\end{array}$ & 30 & 15 & 15 & 15 & 30 & 15 & $\begin{array}{l}\text { Included } \\
\text { in Above }\end{array}$ & $N / A$ \\
\hline $\begin{array}{l}\text { Engineering and } \\
\text { management }\end{array}$ & 11 & 33 & 40 & 41 & 17 & 66 & $\begin{array}{l}\text { Included } \\
\text { in Above }\end{array}$ & $N / A$ \\
\hline Contingency & 13 & 39 & 45 & 47 & 15 & 77 & 42 & N/A \\
\hline $\begin{array}{l}\text { Total Installed } \\
\text { Cost }(1979 \$ / \mathrm{kW})\end{array}$ & 266 & 292 & 344 & 356 & 304 & 581 & 317 & $185^{\prime}$ \\
\hline
\end{tabular}

(a) $\$ 185 / \mathrm{kW}$ is the TAG suggested value for an advanced design gas turbine. 
hand, had the higher $A D I A B / K N U$ estimate been used as the adiabatic representative, only the Case 4 ranking would have been altered since the low capacity factor would have resulted in a heavy loading of fixed cost on the levelized cost of electricity. 


\section{CONCLUSIONS}

The following conclusions are made with respect to the economic performance of compressed air energy storage systems:

- The economic ranking of conventional CAES, hybrid CAES, adiabatic CAES, and gas turbines for the generation of peak-demand electrical power is highly dependent upon fuel oil prices and compression energy costs.

- Given today's fuel oil prices, CAES systems appear to enjoy tremendous cost savings over the more traditional gas turbine systems for a wide range of systems applications and compression energy costs.

- Given today's fuel oil prices, adiabatic systems appear to be slightly more economical than conventional CAES systems.

- The estimating procedures for advanced CAES technology need to be more systematized to enable comparisons of different designs and identification of most promising candidates. 



\section{REFERENCES}

EPRI Technical Assessment Guide. EPRI PS-866-SR, Electric Power Research Institute, PaTo Alto, CA, June 1978.

G. T. Flynn and J. L. Nash-Webber, Application and Design of Compressed Air Energy Storage for Solar Applications - Final Report. CAES-7, Massachusetts Institute of Technology, Lincoln Laboratory, Lexington, MA, September 1979.

I. Glendenning, et al., Technical and Economic Assessment of Advanced Compressed Air Storage (ACAS) Concepts, Central Electric Generating Board, Marchwood Engineering Laboratory, Southampton, SEZ, England, March 1979.

C. A. Knutsen, Incremental Cost Analysis of Advanced Concept CAES Systems. PNL-3118, Knutsen Research Services, Bothe17, WA, for Pacific Northwest Laboratory, Richland, WA, September 1979. 


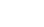


PNL -3191

UC-94b

\section{DISTRIBUTION}

No. of

Copies

OFFSITE

A. A. Churm

DOE Chicago Patent Group

Chicago Operations Office

9800 South Cass Avenue

Argonne, IL 60439

27 DOE Technical Information Center

B. J. Mueller

Department of Energy

Chicago Operations Office

9800 S. Cass Avenue

Argonne, IL 60439

Chief, APMBR

Division of Energy Storage Systems

U.S. Department of Energy

Washington, DC 20585

Dan $\mathrm{Ha} 11$

P.0. 635

Fairvault, MN 55021

Roya 7 B. Newman

Soyland Power Cooperative, Inc.

PO Box A1606

Decatur, IL 62525

G. D. Pezdirtz, Director

Division of Energy Storage Systems

U.S. Department of Energy

Washington, DC 20585

5 Gabor D. Karadi

Department of Energy

Division of Energy Storage

600 E Street, Room 416

Washington, DC 20545
No. of

Copies

5 Saul Strauch

DOE Division of Energy Storage Systems

Advanced Physical Methods

Branch

600 E Street, Room 416

Washington, DC 20585

J. H. Swisher

Division of Energy Storage Sys tems

U.S. Department of Energy

Washington, DC 20585

D. W. Boehm

Division of Environmental Control Technology

U.S. Department of Energy

Washington, DC 20585

Assistant Director for Major

Projects

Division of Solar Energy

U.S. Department of Energy

Washington, DC 20585

Assistant Director for Thermal

Power Systems

Division of Solar Energy

U.S. Department of Energy

Washington, DC 20585

DOE Library

U.S. Department of Energy

Mail Station G-043

Washington, DC 20585

R.F. Kimberlin

DOE Library

U.S. Department of Energy

Room 1223

Washington, DC 20585 
No. of

Copies

D. Willett

Acres American, Inc.

Liberty Bank Building

Main at Court

Buffalo, NY 14202

L. A. Wilson

Middle South Services

P.0. Box 61000

New Orleans, LA 70161

G. T. Flynn

Energy Systems Engineer

MIT/Lincoln Laboratory

Lexington, MA 02173

J. P. Joyce

NASA Lewis Research Center

21000 Brookpark Road

Cleveland, $\mathrm{OH} 44135$

Division of Advanced Energy Research and Technology National Science Foundation Room 1140

1800 G Street, NW

Washington, DC 20550

C. G. Nelson

Manager, Storage Operations

Northern 117 inois Gas Company

P.0. Box 190

Aurora, IL 60507

P. E. Schaub

Potomac Electric Power

Company

1900 Pennsylvania Avenue

Washington, DC 20006

T. McCafferty

Public Service Company

of Indiana

1000 E. Main Street

Plainfield, IN 46168
No. of

Copies

2 Technical Library

Department 3141

Sandia Laboratory

Albuquerque, NM 87115

J. Rasmussen

PEPCO

1900 Pennsylvania Avenue, N.W.

Washington, DC 20068

S. Serata

Serata Geomechanics, Inc.

1229 Eighth Street

Berkeley, CA 94710

Energy Research Section

Tennessee Valley Authority

1360 Commerce Union Bank B1dg.

Chattanooga, TN 37401

Gerald Phillips

Tennessee Valley Authority

1150 Chestnut, Tower 2

Chattanooga, TN 37401

E. Berman

Technical Library

TRW Energy Systems Group

7600 Colshire Drive

McLean, VA 22101

E. H. King

Underground Design Consultants 820 Cascade Bldg.

Portland, OR 97204

A. I. Giramonti

United Technologies Research Center

Silver Lane

East Hartford, CT 06108

H. J. Pincus

University of Wisconsin

Department of Geological

Sciences

Sabin Hall and Greene Museum

P.0. Box 413

Milwaukee, WI 53201 
No. of

Copies

D. Ayers

Manager, Fluid Systems Laboratory

Westinghouse Electric

Corporation

1291 Cumberland Avenue

West Lafayett, IL 47906

American Public Power Association

2600 Virginia Avenue, NW Washington, DC 20037

2 J. M. Clinch

Argonne National Laboratory

9700 South Cass Avenue

Argonne, IL 60439

Manager, Research and Development

Bonneville Power Administration

P.0. Box 3621

Portland, OR 97208

Research Library, Reference Section

Information Division

Brookhaven National Laboratory

Upton, NY 11973

Stanley Stys

Vice President, American

Brown Boveri Corporation

New Brunswick, NJ 08902

Director of Research

Cincinnati Gas and and Electric Company

139 East Fourth Street

Cincinnati, $\mathrm{OH} 45202$

D. E. DeViney

Commonwealth Edison

Company

1319 South First Avenue

Maywood, IL 60153
No. of

Copies

\author{
R. A. Bel1 \\ Consolidated Edison Company \\ 4 Irving Place \\ New York, NY 10003 \\ T. Schneider \\ Electric Power Research \\ Institute \\ Box 10412 \\ Palo Alto, CA 94303 \\ D. Anderson \\ Fenix and Scisson, Inc. \\ P.0. Box 15609 \\ Tulsa, OK 74115 \\ Director of Research \\ GPU Service Corporation \\ 260 Cherry Hill Road \\ Parsippany, NJ 07054
}

A. H. Barber

Director of Marketing

Harza Engineering Company

$150 \mathrm{~S}$. Wacker Drive

Chicago, IL 60606

Library

Lawrence Berkeley Laboratory

University of California

Bldg. 50, Room 134

Berkeley, CA 94720

3 Technical Information

Department, L-3

Lawrence Livermore Laboratory

University of California

P.0. Box 808

Livermore, CA 94550

Director of Research

Louisiana Power and Light

142 Delaronde Street

New Orleans, LA 70174 
No. of

Copies

I. GTendenning

Head of Long-Term Studies

Marchwood Engineering Labs

Southampton, England

A. Ferreira

Electric Power Research

Institute

NEPLAN

174 Brush Hill Avenue

West Springfield, MA 01089

W. Stevens

Project Manager

Electric Power Research

Institute

3412 Hillview Avenue

PO Box 10412

Palo Alto, CA 94303

Fred Ahrens

Argonne National Laboratory

9700 South Cass Avenue

Argonne, IL 60439

Paul Gnirk

$\mathrm{Re} / \mathrm{Spec}$ Inc.

PO Box 725

Rapid City, SD 57701

Donald L. Katz

Department of Chemical

Engineering

The University of Michigan

2042 E. Engr. B Idg.

Ann Arbor, MI 48109

Bob Holliday

Project Manager

Department of Energy

600 "E" Street

Washington, D.C. 20545

R. L. Thoms

Louisiana State University

Institute for Environmental

Studies

Room 42, Atkinson $\mathrm{Hall}$

Baton Rouge, LA 70803
No. of

Copies

0.C. Farquhar

U. of Massachusetts

Dept. of Geology \& Geography

Morrill Science Center

Amherst, MA 01003

T. L. Brekke

University of California

Department of Civil Engineering

1847 Yosemite Road

Berkeley, CA 94707

H. Lorenzen

PB-KBB Inc.

Subservice Systems \& Technology

800 Commerce Road West

Harahan, LA 70123

A. H. Warnke

Vice President Power Supply

Central Illinois Public Service Co.

607 East Adams Street

Springfield, IL 62701

Mr. G. E. Huck

Manager of Planning

Illino is Power Company

500 South 27 th St.

Decatur, IL 62525

Mr. W. C. Walke

Project Manager

Sargent \& Lundy Engineers

55 East Monroe Street

Chicago, IL 60603

T. J. Maiman

Sta. Mech. Engr. Dept. Manager

Commonwealth Edison Co.

$36 \mathrm{FN}$ West

PO Box 767

Chicago, IL 60690

E. M. Mabuce

Manager-Applied Research

Corporate Planning Dept.

Union Electric Co.

PO Box 149

St. Louis, M0 63166 
No of

Copies

W. F. Kobett

CAES Project Manager

Westinghouse Electric Corp.

Combustion Turbine Sys. Div.

Long Range Development-Lab 100

PO Box 251

Concordvil1e, PA 19331

J. C. Smith

Division of Electrical Energy Systems

Department of Energy

20 Massachusetts Ave, Room 2205

Washington, DC 20545

J. Gahimer

Department of Energy

600 "E" Street

Washington, DC 20545

C. Holt

Battelle Columbus Laboratories

505 King Avenue

Columbus, $\mathrm{OH} 43201$

T. Barlow

Lawrence Livermore Laboratory

PO Box 808

Livermore, CA 94550

M. Dodd

Organization 5743

Sandia Labs

A1buquerque, NM 87115

R. 0. Woods

Sandia Laboratories

Org. No. 4715

A1buquerque, NM 87115

J. L. Nash-Webber

MIT

Energy Lab

Cambridge, MA 02139

5 S. C. Schuite

$\mathrm{CH} 2 \mathrm{M} \mathrm{Hill}$ Inc.

1500 114th S.E.

Bellevue, WA 98004
No. of

Copies

ONSITE

DOE Richland Operations

Office

D. K. Jones

H. E. Ransom

67 Pacific Northwest Laboratory

R.D. Alten

R.T. Al Jemann

M.C.C. Bampton

J.M. Bates

H.J. Bomelburg

D.B. Cearlock

T.J. Doherty

D.W. Dragnich

M.K. Drost

R.L. Erikson

J.A. Fort

J.R. Friley

P.J. Gutknecht

A.J. Haverfield

J.J. Jacobson

L.D. Kannberg

W.V. Loscutoff (30)

R.A. McCann

M.A. Mckinnon

L.T. Pedersen

R.W. Reilly (5)

R.P. Smith

J.A. Stottlemyre

A.M. Sutey

D.S. Trent

R.A. Walter

L.E. Wiles

Technical Information (5)

Publishing Coordination (2) 


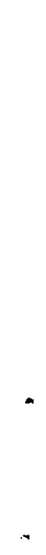

$+$ 